\title{
Epidemiology of Major Eye Diseases Leading to Blindness in Europe: A Literature Review
}

\author{
Elena Prokofyeva Eberhart Zrenner \\ Institute for Ophthalmic Research, Centre for Ophthalmology, University of Tübingen, Tübingen, Germany
}

\section{Key Words}

Age-related macular degeneration - Diabetic retinopathy European data $\cdot$ Epidemiology $\cdot$ Glaucoma $\cdot$ High intraocular pressure $\cdot$ Incidence $\cdot$ Ocular hypertension • Hypertension • Prevalence

\begin{abstract}
The objective of this work was to study the epidemiology of major eye diseases leading to blindness in Europe through a systematic literature review. The literature search was performed using the Medline database (PubMed), with MeSH and free text search terms. Inclusion criteria for the studies were: (a) performed on a healthy population of Caucasian origin aged between 50 and 75 years; (b) diagnosed by ophthalmological examination in accordance with the International Classification of Diseases 10; (c) contained a detailed description of the sampling and diagnostic procedures and data resources; (d) sample size $>500$, and (e) published between 1990 and 2008. The results of 57 studies on the prevalence and incidence of age-related macular degeneration, diabetic retinopathy and glaucoma are reported, providing an up-to-date and comprehensive overview of these diseases in Europe from an epidemiological perspective.
\end{abstract}

Copyright $\odot 2011$ S. Karger AG, Basel

\section{Introduction}

Since many eye diseases are age-related, current increases in life expectancy are bound to have a major influence on the epidemiological profile of reduced vision and blindness in highly developed European countries. Currently, it is estimated that 45 million persons worldwide are blind, with an increase of 1-2 million each year [1].

Age-related macular degeneration (AMD) (26\%), glaucoma $(20.5 \%)$ and diabetic retinopathy $(8.9 \%)$ are the most frequent causes of blindness in Europe [2]. Public health efforts should focus on the above-mentioned conditions, as they represent the most frequently reported causes of visual disability in Europe and can be prevented or cured through proved cost-effective interventions. In other words, they represent the major causes of avoidable blindness and visual impairment [2]. Reliable European epidemiological data are needed for planning of prevention and intervention strategies tackling these economically relevant diseases.

Many epidemiological studies on age-related eye disorders have been carried out in the USA [3-11]. On the other hand, only few literature reviews on this question have been published in Europe. As a result, European

\section{KARGER}

Fax +4161306 1234 E-Mail karger@karger.ch www.karger.com (c) 2011 S. Karger AG, Basel

0030-3747/12/0474-0171\$38.00/0

Accessible online at:

www.karger.com/ore
Dr. med. Elena Prokofyeva, MD, MPH, PhD

Institute for Ophthalmic Research

Centre for Ophthalmology, University of Tübingen

Frondsberstrasse 23, DE-72076 Tübingen (Germany)

E-Mail elena.prokofyeva@biomed-engineering.de 
health services and research policies still lack the myriad benefits of such collated information.

Moreover, existing studies focus for the most part only on a single eye disorder, such as AMD [12-14], diabetic retinopathy [15-17], glaucoma $[18,19]$ or cataract $[20,21]$. Despite the high value of the data from these studies, there is still a pressing need for a complete picture of the epidemiological status of age-related eye diseases in $\mathrm{Eu}$ rope.

The present study therefore undertook to describe the present status of epidemiological research on the prevalence and incidence of major eye diseases leading to blindness in Europe through a systematic literature review. The aim was to identify the individual impact of each eye disorder in relation to age and to compare the results among different European countries.

\section{Search Strategy and Selection Criteria}

A literature search was performed in the Medline database (PubMed), using the controlled vocabulary (MeSH) search terms 'AMD/epidemiology'[Mesh], 'AMD/statistics and numerical data'[Mesh], 'Glaucoma/epidemiology'[Mesh] and 'Glaucoma/ statistics and numerical data'[Mesh], 'Diabetic retinopathy/ epidemiology'[Mesh], 'Diabetic retinopathy/statistics and numerical data'[Mesh], and the free text search terms 'AMD', 'diabetic retinopathy', 'glaucoma', 'high intraocular pressure', 'ocular hypertension', 'prevalence', 'incidence', 'population-based', 'crosssectional', 'longitudinal cohort studies', 'epidemiology' and 'statistical data'.

Only those studies were included which: (a) were carried out in a generally healthy population of Caucasian origin aged 50 and older, (b) were based on diagnoses made by ophthalmological examination in accordance with International Classification of Diseases; (c) included a detailed description of sampling and diagnostic procedures as well as data resources; (d) involved a sample size $>500$, and (e) were published between January 1990 and December 2008.

Articles written in English, Spanish, German, Russian, and French were assessed. Only studies using standardized procedures for disease diagnosis were included. The abstracts of the articles identified were reviewed and those considered of high and medium relevance were obtained. Additionally, attention was also given to articles referenced in the selected articles. Special attention was given to studies focusing on prevalence and incidence by age and gender. Prevalence quantifies the proportion of individuals in a population who have a disease at a specific instant. Incidence quantifies the number of new events or cases of the disease that develop in a population of individuals at risk during a specific time interval. The results will be shown here via colourcoded maps of Europe for crude incidence and prevalence values and in tables for age- and sex-specific indicators. Clinical outcomes, risk factors, disease progression, the socio-economic impact on blindness caused by major eye diseases, and the most effective treatment strategies were noted and will be discussed here.

\section{Results}

The present study reviewed, to the best of the authors' knowledge, all relevant European studies on the epidemiology of major eye diseases. Fifty-seven studies published from 1990 to 2008 met the inclusion criteria: 13 European studies on AMD (4 multicentre studies [13, 22-24], 6 prevalence studies from the Netherlands [25], Germany [26], France [27], the UK [28], the European North of Russia [29] and Bulgaria [2], and 3 incidence studies from Rotterdam [22, 30] and Germany [31]), 23 studies of diabetic retinopathy (1 global [32], 3 European [33-35]; 2 multicentre European $[15,36,37]$ and 2 multicentre from Spain [38] and Germany [26, 39], 1 long-term follow-up study from Germany [40]; 7 population-based studies [2, $30,31,41-45], 5$ cross-sectional studies from Germany [39], France [46], Europe [27, 37], Spain [47] and 2 literature reviews $[16,35]), 5$ studies of ocular hypertension, including 4 cross-sectional studies: 1 from Spain [48], 2 from France [49, 50], 1 cross-sectional study of high intraocular pressure [51], and 1 longitudinal study from Austria [52]; 17 glaucoma studies including 2 prospective longitudinal studies from the UK [53, 54], 6 populationbased studies: 1 from Bulgaria [2], 1 from the European North of Russia [29, 36], 1 from Italy [2], 3 from the Netherlands [1, 2, 45], 4 cross-sectional studies: 2 from Russia $[55,56], 1$ from France [46, 49] and 1 from Spain [48] and 4 incidence studies: 1 from the European North of Russia [56], 2 from Germany [31, 57], and 1 from the UK [54]. The data on prevalence will be reported here in percent, with 95 or $99 \%$ confidence intervals (CIs); incidence will be presented in percent or in the number of cases per population size or person-years.

\section{Epidemiology of AMD}

AMD is the most common cause of severe vision loss worldwide and is characterized by the loss of central vision. Blindness due to AMD occurs at advanced age; over $80 \%$ of those affected become blind after 70 years of age [58]. AMD has two forms: 'wet' (i.e. neovascular and exudative) AMD and 'dry' AMD. Dry AMD tends to progress more slowly than wet AMD [22]. The prevalence of AMD in individuals aged 65-75 ranged between 9 and 25\% [22]. It is higher in women [1.03\% (95\% CI: 0.11-1.96)] than in men [0.90\% (95\% CI: 0-2.08)] at 65-69 years of age, and changes with age, with a greater increase in women from $1.03 \%$ (95\% CI: $0.11-1.96)$ at $65-69$ years of age to $2.36 \%$ (95\% CI: $1.00-3.73$ ) at $70-74$ years of age [13]. The propor- 
Fig. 1. Prevalence of AMD in Europe according to available data.

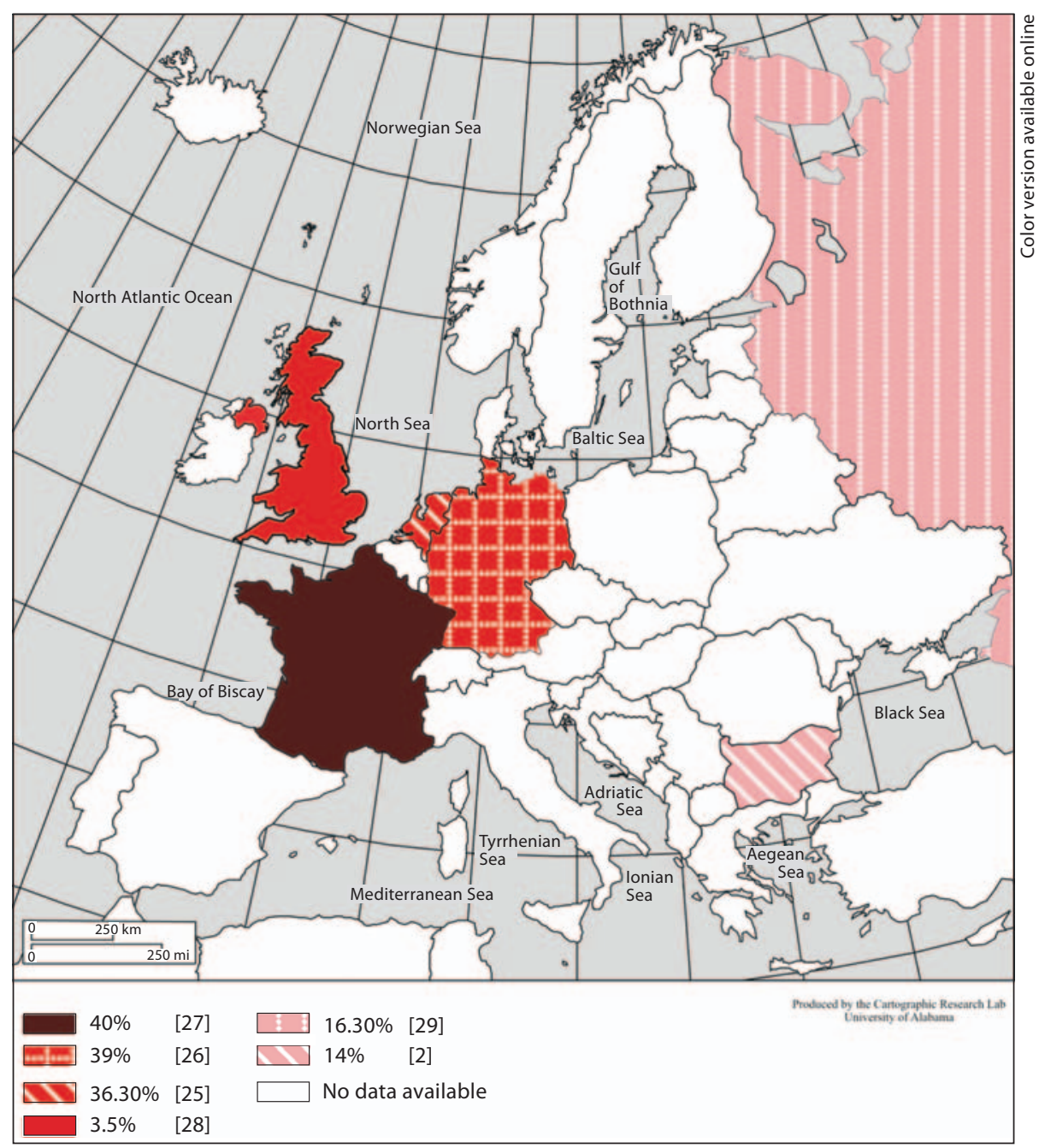

tion of visual impairment due to AMD has been found to vary between $40 \%$ in France [27], 39\% in Germany [26], $36.3 \%$ in the Netherlands [25], 16.30\% in the European North of Russia [29], and 14\% in Bulgaria [2]. A pooled estimate of AMD prevalence showed that $3.5 \%$ (95\% CI: 3.0-4.1) of individuals 75 years or older in the UK had AMD [28]. The incidence rate of AMD increased with age from 0 (95\% CI: 0-1.0) for the age group 55-64, 0.75 (95\% CI: $0.15-2.2)$ for the age group 65-74 and 3.07 (95\% CI: 1.1-6.7) for the population between 74 and 84 years of age [30]. Owen et al. [28] estimated that there are 172,000 individuals (95\% CI: 106,000-279,000) with geographic AMD and 245,000 (95\% CI: 163,000-364,000) with neovascular AMD in the UK. This study showed that neovascular AMD is the more common cause of blindness registration and leads to more rapid visual loss in comparison to geographic AMD [28]. Importantly, this study also un- derlines that patients with geographic AMD tend to present at the eye hospital at early disease stages whereas those with neovascular AMD are more likely to present acutely at late disease stages. This should be taken in consideration when comparing the prevalence and incidence of these AMD subtypes.

The studies discussed here are different in design: a study by Owen et al. [28] is a systematic review with subsequent use of the pooled data for the UK, whereas a study by Cohen et al. [27] is a hospital-based prospective study, which was undertaken in a semi-rural area of France. On the other hand, a Rotterdam population-based cohort study on individuals of 55 years of age and older reports $36.3 \%$ patients with AMD at a baseline [25]. All of these studies used different age group definition criteria and had different study designs and settings, which makes direct comparison of their results problematic. 
Fig. 2. Incidence of AMD in Europe according to available data.

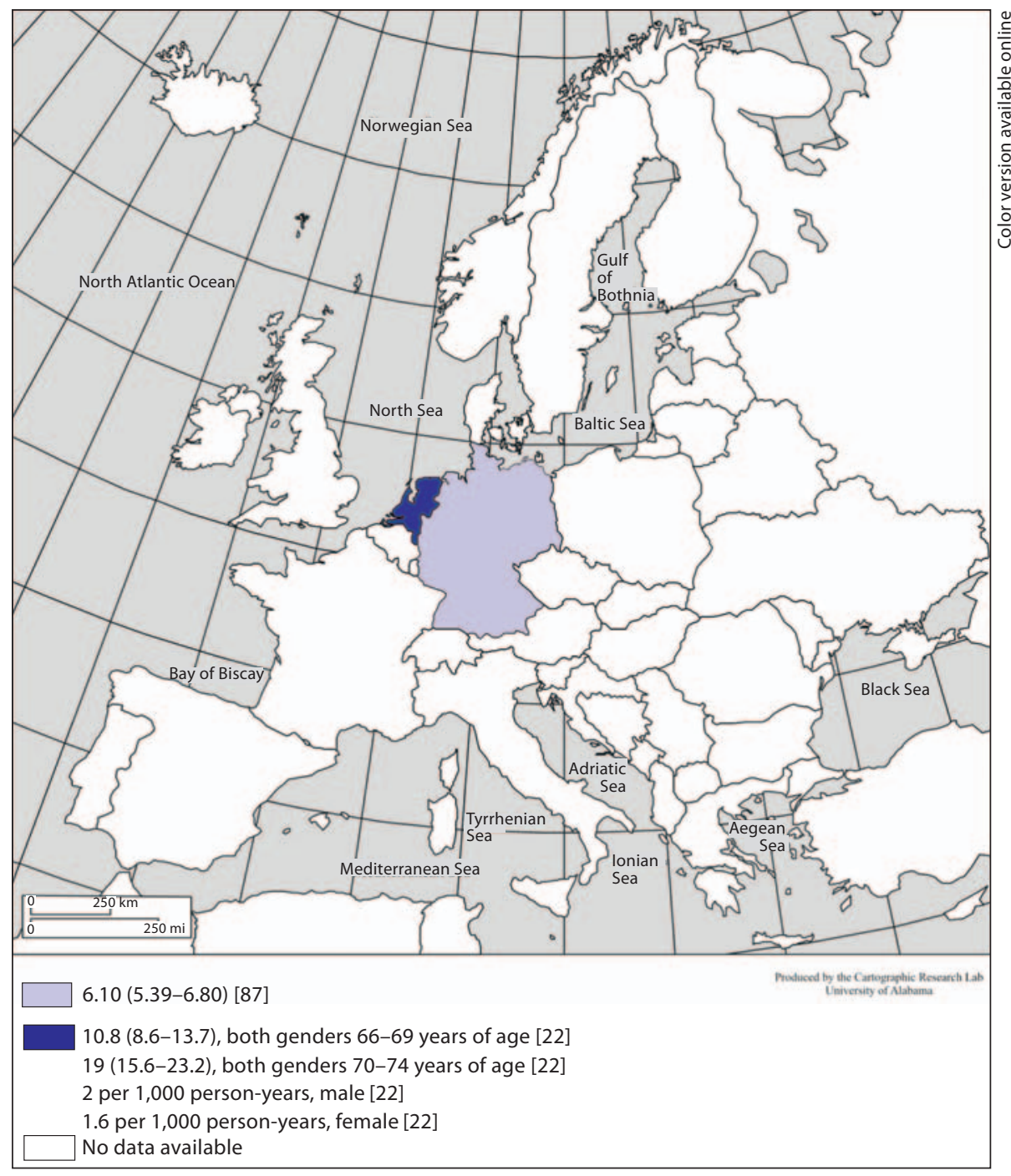

A population-based prospective cohort study with a follow-up period of 6.5 years and a total number of 6,418 participants performed in Rotterdam showed that the crude incidence rate of AMD in men was 2.0 per 1,000 person-years and 1.6 per 1,000 person-years in women; this difference was not significant when corrected for age [rate ratio, 0.7 (95\% CI: 0.4-1.2) (women vs. men)] [22]. The most recent population-based study in Germany indicated that the incidence of blindness due to AMD in Germany is 3.93 per 100,000 [31]. Figure 1 shows a map of the overall prevalence of AMD in Europe. Figure 2 shows the incidence of AMD in Europe. Data on the prevalence and incidence of AMD by age and gender are shown in table 1. Age- and sex-specific prevalence of different AMD types is listed in table 2.

\section{Clinical Outcomes and Socio-Economic Impact of AMD}

\section{Clinical Outcomes}

AMD is the leading cause of severe visual loss in persons older than 65 years [49,59]. Overall, 25-30 million individuals worldwide have severe visual loss due to AMD [60]. Neovascular (exudative or wet) AMD represents $10-15 \%$ of all cases of AMD and accounts for more than $90 \%$ of severe visual loss due to AMD. Patients with bilateral neovascular AMD report a substantially lower quality of life, poorer vision-related functioning, greater anxiety and depression, more frequent falls and fractures, and greater dependency on caregivers. From a clinical perspective, the adverse effects of AMD are a reduc- 
Table 1. Prevalence and incidence of AMD by age and gender in the reviewed studies

\begin{tabular}{|c|c|c|c|c|c|c|c|c|c|}
\hline $\begin{array}{l}\text { Study name/ } \\
\text { country }\end{array}$ & Design & $\begin{array}{l}\text { Sample } \\
\text { size }\end{array}$ & $\begin{array}{l}\text { Study year/ } \\
\text { follow-up } \\
\text { period }\end{array}$ & $\begin{array}{l}\text { Age } \\
\text { groups }\end{array}$ & Gender & Prevalence & Incidence & Remarks & $\begin{array}{l}\text { Ref. } \\
\text { No. }\end{array}$ \\
\hline \multirow{4}{*}{$\begin{array}{l}\text { Eureye } \\
\text { (European } \\
\text { Eye Study) }\end{array}$} & \multirow{4}{*}{$\begin{array}{l}\text { multicenter } \\
\text { population-based } \\
\text { cross-sectional }\end{array}$} & \multirow[t]{4}{*}{4,753} & \multirow[t]{4}{*}{2006} & $65-69$ & male & $0.90(0-2.08)$ & & \multirow{4}{*}{$\begin{array}{l}\text { SQ and } \\
\text { OPHTH }\end{array}$} & \multirow[t]{4}{*}{13} \\
\hline & & & & $70-74$ & male & $1.97(0.77-3.17)$ & & & \\
\hline & & & & & female & $2.36(1.00-3.73)$ & & & \\
\hline & & & & $>65$ & both & $3.3(2.5-4.1)$ & & & \\
\hline \multirow{7}{*}{$\begin{array}{l}\text { Thessaloniki } \\
\text { Eye Study, } \\
\text { Greece }\end{array}$} & \multirow[t]{7}{*}{$\begin{array}{l}\text { cross-sectional } \\
\text { population-based }\end{array}$} & \multirow[t]{7}{*}{2,554} & \multirow[t]{7}{*}{2006} & $60-64$ & $\begin{array}{l}\text { male } \\
\text { female }\end{array}$ & $\begin{array}{l}0.62 \% \\
0.67 \%\end{array}$ & & \multirow[t]{7}{*}{ ОРНТН } & \multirow[t]{7}{*}{13} \\
\hline & & & & $65-69$ & male & $0.82 \%$ & & & \\
\hline & & & & & female & $1.23 \%$ & & & \\
\hline & & & & $70-74$ & $\begin{array}{l}\text { male } \\
\text { female }\end{array}$ & $\begin{array}{l}2.06 \% \\
1.96 \%\end{array}$ & & & \\
\hline & & & & $75-79$ & male & $2.78 \%$ & & & \\
\hline & & & & & female & $3.54 \%$ & & & \\
\hline & & & & $>80$ & $\begin{array}{l}\text { male } \\
\text { female }\end{array}$ & $\begin{array}{r}10.95 \% \\
8.75 \%\end{array}$ & & & \\
\hline \multirow[t]{3}{*}{ UK } & \multirow{3}{*}{$\begin{array}{l}\text { literature } \\
\text { review study }\end{array}$} & \multirow[t]{3}{*}{98,757} & \multirow[t]{3}{*}{2001} & \multirow[t]{3}{*}{$65-79$} & male & $0.15(0.03-0.27)$ & & & \multirow[t]{3}{*}{28} \\
\hline & & & & & female & $0.21(0.09-0.33)$ & & & \\
\hline & & & & & both & $0.35(0.14-0.57)$ & & & \\
\hline Germany & $\begin{array}{l}\text { retrospective } \\
\text { longitudinal study }\end{array}$ & 3,531 & $1994-1998$ & $60-79$ & both & & $6.10(5.39-6.80)$ & ОРНTH & 59 \\
\hline \multirow{4}{*}{$\begin{array}{l}\text { Rotterdam, } \\
\text { Netherlands }\end{array}$} & \multirow{4}{*}{$\begin{array}{l}\text { population-based } \\
\text { prospective cohort } \\
\text { study }\end{array}$} & \multirow[t]{4}{*}{6,418} & \multirow{4}{*}{$\begin{array}{l}2003 / \\
6.5 \text { years }\end{array}$} & $66-69$ & both & & $10.8(8.6-13.7)$ & \multirow{4}{*}{$\begin{array}{l}\text { SQ, FI, } \\
\text { OPHTH }\end{array}$} & \multirow[t]{4}{*}{22} \\
\hline & & & & $70-74$ & both & & $19(15.6-23.2)$ & & \\
\hline & & & & & male & & 2 per 1,000 person-years & & \\
\hline & & & & & female & & 1.6 per 1,000 person-years & & \\
\hline
\end{tabular}

The grading of AMD is based on an international classification and grading system for AMD and ARMD. SQ = Standard questionnaire; FI = fundus image; OPTH = ophthalmological examination.

Table 2. Age- and sex-specific prevalence of AMD types

\begin{tabular}{|c|c|c|c|c|c|c|c|c|c|}
\hline Type of AMD & $\begin{array}{l}\text { Study } \\
\text { location }\end{array}$ & Study design & $\begin{array}{l}\text { Sample } \\
\text { size }\end{array}$ & Year & $\begin{array}{l}\text { Age } \\
\text { group }\end{array}$ & Gender & Prevalence & $\begin{array}{l}\text { Method of } \\
\text { diagnosis }\end{array}$ & $\begin{array}{l}\text { Ref. } \\
\text { No. }\end{array}$ \\
\hline Geographic AMD & \multirow[t]{4}{*}{ UK } & \multirow{4}{*}{$\begin{array}{l}\text { literature review } \\
\text { (27 references) }\end{array}$} & \multirow[t]{4}{*}{98,757} & \multirow[t]{4}{*}{2001} & $65-79$ & both & $0.53(0.37-0.68)$ & \multirow[t]{4}{*}{ ОРНTH } & \multirow[t]{4}{*}{28} \\
\hline Neovascular AMD & & & & & $65-79$ & both & $1.05(0.57-1.52)$ & & \\
\hline Geographic AMD & & & & & $65-79$ & $\begin{array}{l}\text { male } \\
\text { female }\end{array}$ & $\begin{array}{l}0.60(0.35-0.85) \\
0.45(0.26-0.64)\end{array}$ & & \\
\hline$\overline{\text { Neovascular AMD }}$ & & & & & $65-79$ & $\begin{array}{l}\text { male } \\
\text { female }\end{array}$ & $\begin{array}{l}0.81(0.52-1.11) \\
1.03(0.49-1.58)\end{array}$ & & \\
\hline $\begin{array}{l}\text { Early AMD } \\
\text { Late AMD }\end{array}$ & Europe & $\begin{array}{l}\text { multinational cross- } \\
\text { sectional study }\end{array}$ & $\begin{array}{l}\text { not } \\
\text { indicated }\end{array}$ & 2008 & $65-74$ & both & $\begin{array}{r}15 \% \\
1 \%\end{array}$ & ОРНТН & 14 \\
\hline $\begin{array}{l}\text { Any AMD } \\
\text { Early AMD } \\
\text { Late AMD }\end{array}$ & $\begin{array}{l}\text { Rotterdam, } \\
\text { Netherlands }\end{array}$ & $\begin{array}{l}\text { prospective } \\
\text { follow-up study }\end{array}$ & 6,781 & $1990-1993$ & $\begin{array}{l}65-74 \\
55-64 \\
65-74\end{array}$ & both & $\begin{array}{l}10 \% \\
2.4 \% \\
9.2 \%\end{array}$ & FIG, OPHTH & 4 \\
\hline
\end{tabular}

The grading of AMD is based on an international classification and grading system for AMD and ARMD.

FIG = Fundus image grading; OPHTH = ophthalmological examination. 
tion in visual acuity, contrast sensitivity and the development of central scotoma $[61,62]$.

\section{Natural Progression of AMD}

A study of the natural progression of untreated agerelated macular degeneration showed that the median time between referral assessment and treatment is 28 days (interquartile range $=36.5$ days); $44 \%$ of the investigated subjects had some degree of visual loss and $16 \%$ lost more than 3 lines of distance visual acuity [63]. The time between initial diagnosis and treatment correlated with the progression of visual loss $(\mathrm{r}=0.50, \mathrm{p}=0.003)$ [63]. Average time from baseline to initial appearance of geographic atrophy is 6.6 years (range $4-11$ ). Time from lesion appearance to onset of geographic atrophy depends on the lesion type and ranges from 2.5 to 5.9 years [64].

\section{Economic Costs}

AMD results in a substantial economic burden. Cruess et al. [64] performed a multicountry observational study of the economic burden of bilateral neovascular AMD. Societal costs including direct vision-related medical costs (e.g. treatment of AMD and vision-related equipment), direct non-vision-related medical costs (e.g. medications) and direct non-medical-related costs (e.g. home healthcare and social services) were measured in this study. In 2005, the annual societal cost per bilateral neovascular AMD varied by country: 7,349 EUR in France, 12,445 EUR in Germany, 5,732 EUR in Spain and 5,300 EUR in the UK [64]. Direct vision-related medical costs accounted for $23-63 \%$ of the total costs [64]. Limited research has been done on the economic burden of neovascular and geographic AMD in Europe. Results of a retrospective, observational, population-based study based on Medicare data showed that median eye-related Medicare costs were USD 1,607 for neovascular AMD patients, USD 832 for non-neovascular/dry AMD patients, and USD 658 for controls [65].

Such a high economic burden highlights both the importance of early AMD screening and the development of new therapies that slow disease progression [66]. Treatment interventions, such as ranibizumab therapy, laser photocoagulation, pegaptanib (macugen) therapy, and photodynamic therapy (PDT) have been shown to improve quality of life, with the highest increase for ranibizumab therapy [67]. An overview of a broad range of costeffectiveness analyses showed that ranibizumab was the most cost-effective therapy for wet AMD in comparison with other approved therapies (e.g. vs. PDT or pegap- tanib). Pegabtanib was found to be cost-effective compared to usual/best supportive care (including PDT) or no treatment only when treatment was initiated in early or moderate stages of disease [68]. PDT was found most likely to be cost-effective when prescribed early to patients with better visual acuity [69]. Laser photocoagulation was also shown to be a cost-effective treatment option for wet AMD treatment. Costs per quality-adjusted life-year (QALY) gained for laser treatment compared to no treatment or observation were USD 5,629-23,176 over a time frame of 11-14 years [70-72]. A Novartis-sponsored literature review underlines that there are no reliable studies on cost-effectiveness of bevacizumab; therefore, off-label use of this treatment strategy is controversial [73]. Additionally, it reports a lack of safety data and little evidence from robust randomized control trials, preventing the proper assessment of the cost-effectiveness of bavacizumab in wet AMD [73]. Most importantly, the pharmacokinetics and pharmacodynamics of bevacizumab are different from those of ranibizumab. Mitchell et al. [73] stress that further robust randomized clinical trials (RCTs) are needed to establish the safety and clinical effectiveness of AMD treatment with bevacizumab. Clinical trials on the efficacy of nutrition components in reducing AMD progression and its prevention are ongoing [74].

\section{Epidemiology of Diabetic Retinopathy in Europe}

Diabetic retinopathy is one of the most sight-threatening complications of diabetes mellitus and one of the most important emerging causes of blindness. It accounts for about 2.4 million cases of blindness globally [75]. A proportion of $4.8 \%$ of the global population has diabetic retinopathy [32], while 3 [32] to $4.1 \%$ [33] of Europeans are affected. According to recent epidemiological data, the prevalence of diabetic retinopathy in individuals over 60 years of age is the highest in France (16.6\%) [46], followed by Germany (10.6\%) [39]. A prospective multinational WHO cohort study that included 4,662 adult participants who were followed up over a period of 8.4 years showed that the incidence of any diabetic retinopathy in patients with type II diabetes was the highest in the UK (43.3\%), followed by Switzerland (42.3\%), Poland (31.8\%), and Germany (29.9\%) [34]. A population-based survey performed in Germany showed that 60- to 74-year-old men had a higher incidence of diabetic retinopathy (29\%) than women in the same age range $(16.51 \%)$ [31]. Mild to moderate diabetic retinopa- 
Fig. 3. Prevalence of diabetic retinopathy among Europeans with type II diabetes according to available data.

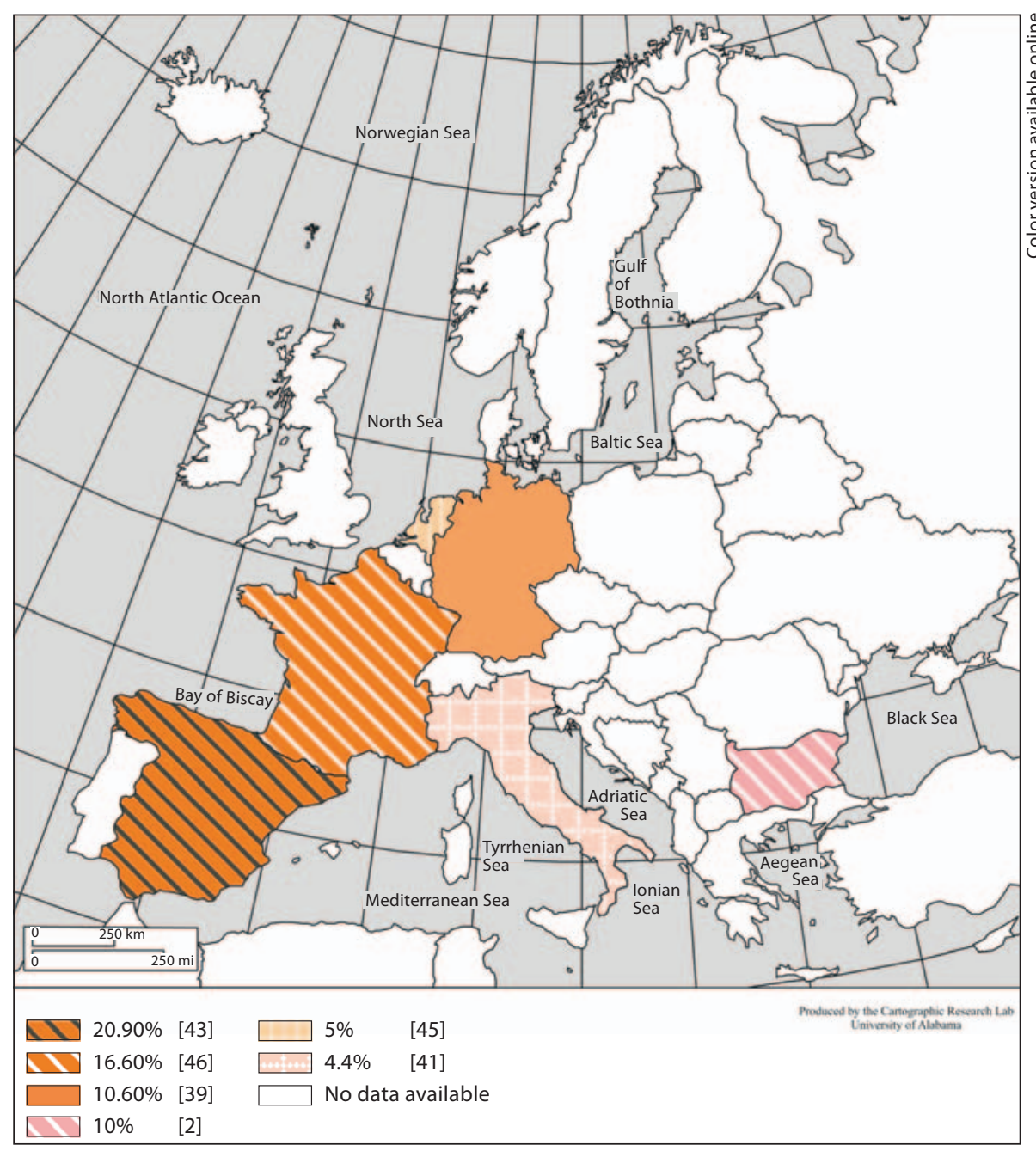

thy (8.5\%) was the most prevalent in Germany followed by non-proliferative (1.7\%) and proliferative diabetic retinopathy $(0.6 \%)$ [39]. In the UK, the overall prevalence of any diabetic retinopathy in diabetic patients residing in the English town of Melton Mowbray was 52\% [42]. The same study demonstrated that $48 \%$ of all patients with diabetic retinopathy had non-proliferative diabetic retinopathy and $4 \%$ had proliferative diabetic retinopathy [42]. The same trend was observed in Spain, where the figures were 38.9 and $5.8 \%$, respectively [28]. A map of the prevalence of diabetic retinopathy is shown in figure 3. The incidence of all forms of diabetic retinopathy is shown in figure 4 . The prevalence of different types of diabetic retinopathy in Europe is shown in table 3.

\section{Clinical Outcomes and Socio-Economic Impact of Diabetic Retinopathy}

\section{Clinical Outcomes}

Diabetic eye disease is one of the leading causes of blindness in the Western world in the 25- to 65-year age group [76]. The most common cause of blindness in patients with diabetes is macular oedema [77]. Morphological changes that lead to blindness frequently develop without any symptoms and remain unnoticed by patients. Nevertheless, changes can be detected by medical examination and treatment is often successful in preserving sight. Reduced vision and blindness caused by diabetic retinopathy are significantly associated with sex, age at the time of examination, age at the time of diagnosis, duration of diabetes, type of diabetes treatment, and hypertension [78]. 
Table 3. Prevalence of different DR types

\begin{tabular}{|c|c|c|c|c|c|c|c|c|c|c|}
\hline Type of DR & $\begin{array}{l}\text { Study } \\
\text { location }\end{array}$ & $\begin{array}{l}\text { Study } \\
\text { design }\end{array}$ & $\begin{array}{l}\text { Sample } \\
\text { size }\end{array}$ & Year & Age & $\begin{array}{l}\text { Gen- } \\
\text { der }\end{array}$ & $\begin{array}{l}\text { Prev- } \\
\text { alence }\end{array}$ & Grading criteria & $\begin{array}{l}\text { Method of } \\
\text { diagnosis }\end{array}$ & $\begin{array}{l}\text { Ref. } \\
\text { No. }\end{array}$ \\
\hline $\begin{array}{l}\text { Non-proliferative DR } \\
\text { Proliferative DR }\end{array}$ & UK & $\begin{array}{l}\text { population- } \\
\text { based survey }\end{array}$ & 215 & 1993 & adults & both & $\begin{array}{l}48 \% \\
4 \%\end{array}$ & criteria were not well described & $\begin{array}{l}\text { information from } \\
\text { hospital records }\end{array}$ & 42 \\
\hline $\begin{array}{l}\text { Non-proliferative DR } \\
\text { Proliferative DR }\end{array}$ & Spain & $\begin{array}{l}\text { population- } \\
\text { based survey }\end{array}$ & 1,179 & 1993 & adults & both & $\begin{array}{l}38.90 \% \\
5.80 \%\end{array}$ & $\begin{array}{l}\text { classification from an early treatment } \\
\text { diabetic retinopathy study }\end{array}$ & $\begin{array}{l}\text { from medical rec- } \\
\text { ord of diabetologic } \\
\text { centers }\end{array}$ & 47 \\
\hline $\begin{array}{l}\text { Non-proliferative DR } \\
\text { Proliferative DR } \\
\text { Mild DR } \\
\text { Mild/moderate DR }\end{array}$ & Germany & $\begin{array}{l}\text { cross- } \\
\text { sectional } \\
\text { population- } \\
\text { based study }\end{array}$ & 5,596 & $\begin{array}{l}2002- \\
2004\end{array}$ & $\begin{array}{l}\geq 65 \\
\text { years }\end{array}$ & both & $\begin{array}{l}1.70 \% \\
0.60 \% \\
0.50 \% \\
8.30 \%\end{array}$ & $\begin{array}{l}\text { recommendation for staging of } \\
\text { proliferative diabetic retinopathy by } \\
\text { Prof. Kroll, Marburg }\end{array}$ & $\begin{array}{l}\text { OPHTH during } \\
\text { general diabetes } \\
\text { screening program, } \\
\text { standardized } \\
\text { protocols }\end{array}$ & 39 \\
\hline $\begin{array}{l}\text { Minimal DR } \\
\text { Mild DR } \\
\text { Moderate DR } \\
\text { Proliferative DR } \\
\text { Moderate or worse DR }\end{array}$ & Europe & survey & 458 & 2007 & adults & both & $\begin{array}{l}16.70 \% \\
16.70 \% \\
1.30 \% \\
2.70 \% \\
4 \%\end{array}$ & $\begin{array}{l}\text { National Diabetes Retinal Screening } \\
\text { Grading System and referral } \\
\text { recommendations. Save Sight Society of } \\
\text { New Zealand Inc., } 2005\end{array}$ & SQ, OPHTH, FI & 25 \\
\hline Proliferative DR & Europe & $\begin{array}{l}\text { multi- } \\
\text { national co- } \\
\text { hort study }\end{array}$ & 29,994 & $\begin{array}{l}2001 \\
(8.4 \text { years } \\
\text { of follow- } \\
\text { up) }\end{array}$ & all ages & both & $36.20 \%$ & $\begin{array}{l}\text { DR classification as described by } \\
\text { Fukuda [107]: preproliferative } \\
\text { retinopathy (PR) (B1), early stage (B2) } \\
\text { Advanced stage (B3), end stage of } \\
\text { proliferative diabetic retinopathy (B4) } \\
\text { Mild to moderate (Al) } \\
\text { Severe simple retinopathy (A2), } \\
\text { moderate interrupted proliferative } \\
\text { retinopathy } \\
\text { Severe interrupted proliferative } \\
\text { retinopathy (A4) }\end{array}$ & $\begin{array}{l}\text { enquiry method, } \\
\text { SQ }\end{array}$ & 16 \\
\hline
\end{tabular}

$\mathrm{DR}=$ Diabetic retinopathy; $\mathrm{SQ}=$ standard questionnaire, $\mathrm{FI}=$ fundus image; $\mathrm{OPHTH}=$ ophthalmological examination.

\section{Natural Progression of Diabetic Retinopathy}

The ocular effects of diabetes are assumed to progress from no retinopathy to background retinopathy and then either to proliferative retinopathy, macular oedema, or both. Patients with asymptomatic macular oedema may develop clinically significant macular oedema that can progress to central visual loss; proliferative retinopathy may also result in visual loss [47]. The prevalence of macular oedema was $1.4 \%$ in Badajoz, Spain, and $0.85 \%$ in Germany $[39,47]$. Early screening and treatment of diabetic retinopathy were shown to be cost-effective.

\section{Economic Costs of Diabetic Retinopathy}

Screening and treatment of diabetic eye disorders in the USA save USD 3,190 per QALY; this refers to a measurement of outcome that takes into account both the quantity and the quality of life provided by health care intervention; it is the arithmetic product of life expectancy and quality of remaining life years [79]. The average cost for detecting and treating diabetic eye disorders in insulin-dependent diabetes mellitus was USD 1,996 per QALY, 2,933 USD for those with non-insulin-dependent diabetes mellitus who use insulin for glycemic control, and USD 2,993 for those with non-insulin-dependent diabetes mellitus who do not use insulin for glycemic control. Screening and prevention programmes thus lead to substantial savings and are costeffective societal health investments [80].

If proliferative retinopathy is untreated, $50 \%$ of patients with retinal neovascularization will be blind within 5 years; $50 \%$ of patients with optic disc neovascularization will be blind within 2 years [81]. Laser photocoagulation performed in the early stages of the disease can lead to a $60 \%$ reduction in severe visual loss at 2 years [78].

\section{Epidemiology of Glaucoma in Europe}

Glaucoma can be classified into two broad types: open-angle and angle-closure glaucoma, each of which can be categorized as primary or secondary [74]. Sixty- 
Fig. 4. Incidence of diabetic retinopathy in European patients with diabetes type II according to available data.



seven million persons globally, of whom 25 million live in Europe, are affected by glaucoma [82]. It has been estimated that $12.3 \%$ of the worldwide population and $21.8 \%$ of European adults (including 18\% of those over 50 years of age) have been diagnosed with glaucoma [32, 35, 83]. Overall, glaucoma is responsible for 5.2 million cases of blindness (15\% of global blindness) [84].

Visual loss in patients with glaucoma is explained by progressive damage to optic nerve fibres. According to recent epidemiological studies, Germany (14\%) [26] shows the highest prevalence of glaucoma in Europe followed by the European North of Russia (11.9\%) [29]. The lowest prevalence of any type of glaucoma has been registered in France (3.4\%) [50] and the UK (3.3\%) [85]. A map of the prevalence of glaucoma in Europe is shown in figure 5 .

A Spanish epidemiological study showed that primary open-angle glaucoma [2.1\% (99\% CI: 1.9-2.3)] was more prevalent in men (2.4\%) than in women (1.7\%) [48]. A cross-sectional study performed in the UK every year from 2000 to 2003 estimated that open-angle glaucoma and ocular hypertension increased both in men (from 3.41 to $3.6 \%$ ) and in women (from 2.96 to $3.12 \%$ ), but the prevalence was always higher in men than in women [86].

A retrospective longitudinal study performed in Southern Germany with 5 years of follow-up and 3,531 participants showed that the incidence of glaucoma was 2.37 (95\% CI: 1.93-2.81) [87]. A cross-sectional study from the European North of Russia estimated the incidence of glaucoma at a level of 1.3 cases in 1,000 persons [56]. A population-based survey with 647 participants aged 60-74 years was performed in Germany in 1999. This study showed that the sex-specific incidence of glaucoma was also higher in men (6.64\%) than in women (2.96\%) [31]. A map of the incidence of glaucoma in Europe is shown in figure 6 . 
Fig. 5. Prevalence of glaucoma in Europe

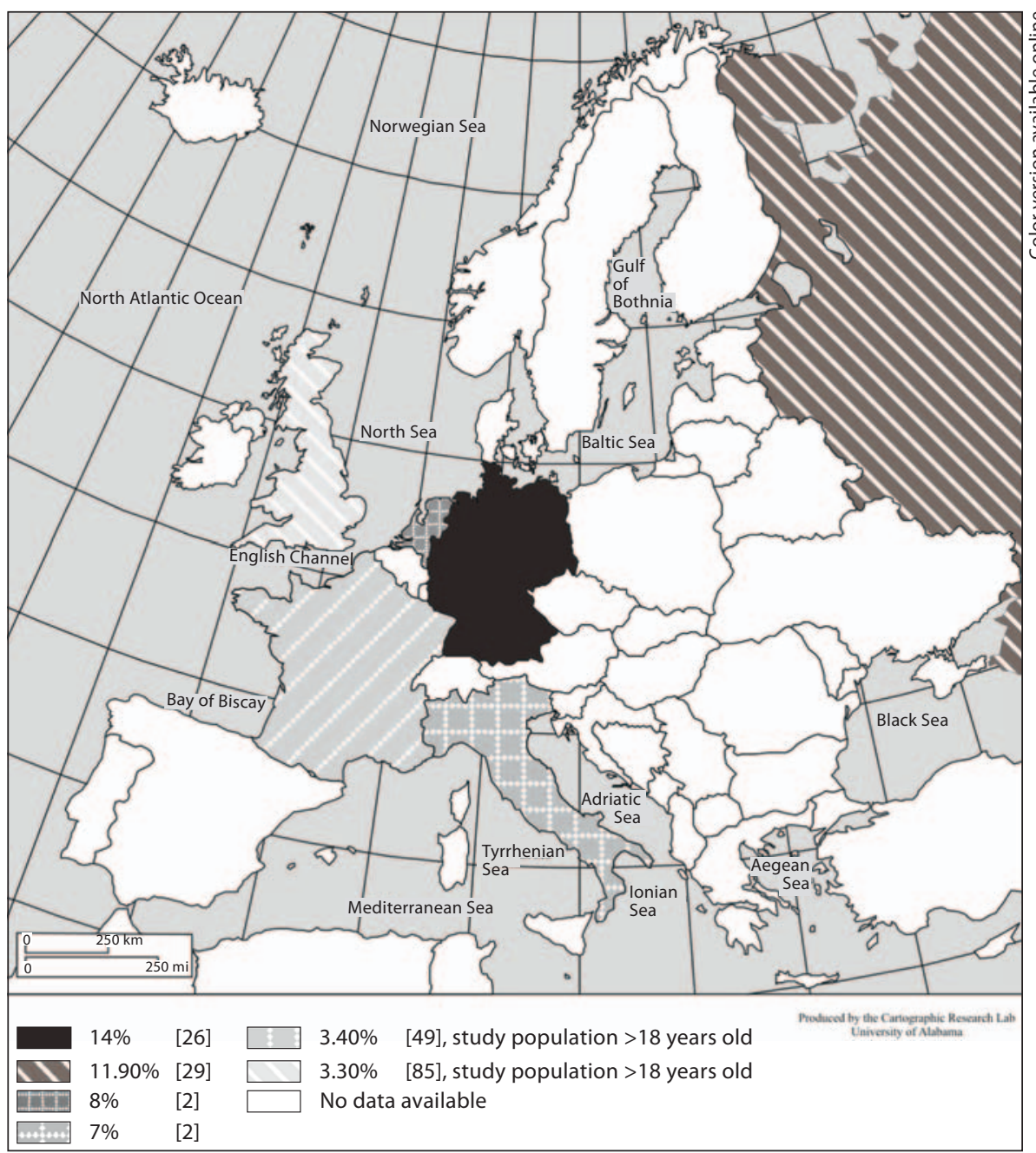
according to available data.

Population projections for the years 2010 and 2020 indicate that open-angle glaucoma will become the most prevalent type of glaucoma in Europe, with a prevalence of 23.9 and $21.1 \%$, respectively [88]. Open-angle glaucoma accounts for $56.5 \%$ of all cases of glaucoma in Russia [35]. On average, this type of glaucoma accounts for $80 \%$ of all cases of glaucoma and becomes more common with increasing age [84]. The age- and sex-specific prevalence of glaucoma in Europe is shown in table 4. The incidence of different types of glaucoma in Europe is shown in table 5.

\section{Clinical Outcomes and Socio-Economic Impact of Glaucoma}

Glaucoma is the second most common cause of blindness among the elderly in developed countries [91]. The number of patients with blindness due to glaucoma in different countries varies between 5 and 33\% [92]. The symptoms of glaucoma are not obvious in its early stages, when treatment can be the most beneficial, and awareness about the early signs and symptoms of glaucoma is low in many countries [93]. Conversion of ocular hypertension to glaucoma is associated with such risk factors as older age, higher intraocular pressure, larger cup-disc ratio, and lower central corneal thickness [94].

A prospective study of medical costs of glaucoma and ocular hypertension performed in Italy showed that the greater the severity of this disorder, the higher the economic losses. The annual average cost per patient was EUR 788.7 and rose significantly with disease severity from EUR 572 for ocular hypertension, EUR 734.3 for glaucoma, and EUR 1,054.9 for advanced glaucoma [95]. A multinational long-term study of direct costs of glaucoma and disease severity demonstrated a statistically significant increasing linear trend $(p=0.018)$ in direct 
Table 4. Age- and sex-specific prevalence of different types of glaucoma

\begin{tabular}{|c|c|c|c|c|c|c|c|c|c|}
\hline $\begin{array}{l}\text { Type of } \\
\text { glaucoma }\end{array}$ & $\begin{array}{l}\text { Study } \\
\text { location }\end{array}$ & Study design & $\begin{array}{l}\text { Sample } \\
\text { size }\end{array}$ & Year & Age & $\begin{array}{l}\text { Gen- } \\
\text { der }\end{array}$ & $\begin{array}{l}\text { Prevalence } \\
\%\end{array}$ & Method of grading & $\begin{array}{l}\text { Ref. } \\
\text { No. }\end{array}$ \\
\hline $\begin{array}{l}\text { OAG } \\
\text { Other types }\end{array}$ & $\begin{array}{l}\text { Rotterdam, } \\
\text { Netherlands }\end{array}$ & $\begin{array}{l}\text { population- } \\
\text { based prospective } \\
\text { cohort }\end{array}$ & 6,781 & 1990-1999 & $65-74$ & both & $\begin{array}{l}22.50 \\
3.30\end{array}$ & $\begin{array}{l}\text { special for this study: incident VF loss } \\
\text { presence of a VF defect in at least one eye } \\
\text { on Goldmann perimetry in a participant } \\
\text { from a cohort at risk or the presence of a } \\
\text { defect of at least six continuous points }\end{array}$ & 45 \\
\hline OAG & Lebanon & $\begin{array}{l}\text { cross-sectional } \\
\text { study }\end{array}$ & 298 & 2007 & $\begin{array}{l}40 \text { years } \\
\text { of age } \\
\text { and older }\end{array}$ & both & 7.30 & criteria were not well described & 46 \\
\hline $\begin{array}{l}\text { OAG } \\
\text { Normal-ten- } \\
\text { sion glaucoma } \\
\text { ACG }\end{array}$ & France & $\begin{array}{l}\text { cross-sectional } \\
\text { study }\end{array}$ & 3,896 & 2003 & $\begin{array}{l}\text { Adults } \\
\text { older than } \\
18 \text { years } \\
\text { of age }\end{array}$ & both & $\begin{array}{l}61.70 \\
3.40 \\
5.50\end{array}$ & $\begin{array}{l}\text { Manual of International Classification of } \\
\text { Diseases, Injuries, and Causes of Death } \\
\text { Geneva: Switzerland: World Health } \\
\text { Organization, } 1977\end{array}$ & 27 \\
\hline $\begin{array}{l}\text { Early POAG } \\
\text { POAG suspect }\end{array}$ & Austria & $\begin{array}{l}\text { long-term } \\
\text { follow-up study }\end{array}$ & 4,864 & $\begin{array}{l}2006 / 8 \text { years } \\
\text { of follow-up }\end{array}$ & Adults & both & $\begin{array}{l}2.9(2.3-3.5) \\
8.5(7.6-9.4)\end{array}$ & $\begin{array}{l}\text { Terminology and Guidelines for Glaucoma } \\
\text { (ed. 3) }\end{array}$ & 52 \\
\hline POAG & Spain & $\begin{array}{l}\text { cross-sectional } \\
\text { population-based }\end{array}$ & 596 & 2004 & Adults & $\begin{array}{l}\text { male } \\
\text { female }\end{array}$ & $\begin{array}{l}2.40 \\
1.70\end{array}$ & $\begin{array}{l}\text { POAG: presence of glaucomatous optic } \\
\text { disc + glaucomatous VF changes + intra- } \\
\text { ocular pressure }>21 \mathrm{~mm} \mathrm{Hg}^{1}\end{array}$ & 48 \\
\hline $\begin{array}{l}\text { POAG } \\
\text { Primary ACG }\end{array}$ & Italy & $\begin{array}{l}\text { population } \\
\text { based preva- } \\
\text { lence survey }\end{array}$ & 1,034 & 1997 & $\begin{array}{l}40 \text { years } \\
\text { and older }\end{array}$ & both & $\begin{array}{l}2.51(1.72-3.66) \\
0.97(0.53-1.77)\end{array}$ & $\begin{array}{l}\text { glaucomatous VF defects (sensitivity decrease } \\
\geq 6 \mathrm{db} \text { in at least one location of the central } \\
10^{\circ} \text {, two locations for the central } 20^{\circ} \text { or three } \\
\text { locations of the central } 30^{\circ}, \mathrm{IOP}>20 \mathrm{~mm} \mathrm{Hg} \text {, } \\
\mathrm{CDR}>0.5 \text {, difference in CDR }>0.2\end{array}$ & 51 \\
\hline POAG & Austria & cohort study & 853 & $2007 / 5$ years & $\begin{array}{l}\leq 50 \\
\geq 60\end{array}$ & both & $\begin{array}{l}0.7(0.3-1.9) \\
6.9(1.7-24)\end{array}$ & $\begin{array}{l}\text { Terminology and Guidelines for Glaucoma } \\
\text { (ed. 3) }\end{array}$ & 89 \\
\hline OAG & $\begin{array}{l}\text { Thessaloniki, } \\
\text { Greece }\end{array}$ & $\begin{array}{l}\text { cross-sectional, } \\
\text { population } \\
\text { based study }\end{array}$ & 2,554 & 1999 & $\begin{array}{l}>60 \\
60-64 \\
65-69 \\
70-74 \\
75-76 \\
>80\end{array}$ & $\begin{array}{l}\text { male } \\
\text { female } \\
\text { both }\end{array}$ & $\begin{array}{l}3.8 \\
3.7 \\
2.6 \\
2.6 \\
4.8 \\
5.3 \\
4.3\end{array}$ & $\begin{array}{l}\text { specific study definition: presents of both } \\
\text { glaucomatous optic nerve and confirmed } \\
\text { glaucomatous VF defects }\end{array}$ & 18 \\
\hline
\end{tabular}

OAG = Open-angle glaucoma; POAG = primary open-angle glaucoma; $\mathrm{ACG}=$ angle-closure glaucoma; $\mathrm{SQ}=$ Standard Questionnaire; $\mathrm{OPHTH}=\mathrm{ophthalmo-}$ logical examination; $\mathrm{VF}=$ visual field. ${ }^{1}$ Not obligatory diagnostic criterion.

Table 5. Incidence of different types of glaucoma

\begin{tabular}{|c|c|c|c|c|c|c|c|c|c|}
\hline $\begin{array}{l}\text { Type of } \\
\text { glaucoma }\end{array}$ & $\begin{array}{l}\text { Study } \\
\text { location }\end{array}$ & Study design & $\begin{array}{l}\text { Sample } \\
\text { size }\end{array}$ & Year & $\begin{array}{l}\text { Age } \\
\text { years }\end{array}$ & Sex & Incidence & Method of diagnosis & $\begin{array}{l}\text { Ref. } \\
\text { No. }\end{array}$ \\
\hline \multirow[t]{2}{*}{ POAG } & $\begin{array}{l}\text { Peterborough, } \\
\text { UK }\end{array}$ & $\begin{array}{l}\text { calculation of the local } \\
\text { prevalence and inci- } \\
\text { dence of POAG using } \\
\text { clinical audit data }\end{array}$ & 164,000 & 2000 & $\begin{array}{l}60-64 \\
65-69 \\
70-74\end{array}$ & both & $\begin{array}{c}33.57(6.92-98.05) \\
122.24(58.68-224.94) \\
136.29(62.43-258.97)\end{array}$ & $\begin{array}{l}\text { definition of glaucoma by Gupta } \\
\text { and Weinreb [89] }\end{array}$ & 54 \\
\hline & Austria & cohort study & 853 & $\begin{array}{l}2007 / 5 \text { years } \\
\text { follow-up }\end{array}$ & $\begin{array}{l}50 \\
60\end{array}$ & both & $\begin{array}{l}0.7 \%(0.3-1.9 \%) \\
6.9 \%(1.7-24 \%)\end{array}$ & $\begin{array}{l}\text { Terminology and Guidelines } \\
\text { for Glaucoma (ed. } 3 \text { ) }\end{array}$ & 90 \\
\hline $\begin{array}{l}\text { Glaucoma, } \\
\text { all types }\end{array}$ & Germany & $\begin{array}{l}\text { retrospective longi- } \\
\text { tudinal study }\end{array}$ & 3,531 & 1994-1998 & $60-79$ & both & $2.37(1.93-2.81)$ & $\begin{array}{l}\text { definition of the European Glauco- } \\
\text { ma Society including definition of } \\
\text { incidence of blindness due to glauco- } \\
\text { ma-BCVA } \leq 1 / 50 \text { in the better eye, } \\
\text { and VF } \leq 5^{\circ}\end{array}$ & 87 \\
\hline
\end{tabular}

OPHTH = Ophthalmological examination; BCVA = best-corrected visual acuity; VF = visual field. 
Fig. 6. Incidence of glaucoma in Europe according to available data.



cost as glaucoma severity worsened. The direct costs of treatment increased from EUR 455 per person-year for stage 0 to EUR 969 per person-year for stage 4 disease, accounting for EUR 86 for each incremental step [96]. These facts stress the importance of early screening, diagnostics and treatment of glaucoma. Several epidemiological studies have shown that at least half of the patients with glaucoma remain undiagnosed [97], whereas more than half of those who are undergoing treatment do not have the disease [98]. More than half of patients who were newly diagnosed with glaucoma during screening have seen an ophthalmologist before, but glaucoma remained undiagnosed [99]. Since there are no early warning symptoms, it was recommended that all adults over 50 years of age be tested for glaucoma every 2 years [95]. Glaucoma has received very little atten- tion from health economists [100]. This can mostly be explained by the lack of major parameters needed for cost-effectiveness analyses such as: limited utility data mostly based on cross-sectional pilot studies, no standards for collation and report of cost data in glaucoma care, and low sample size, special inclusion and exclusion criteria used in RCTs, protocol-driven costs are limiting the application of RCT results to the general population [100].

Lowering of intraocular blood pressure is important for the treatment of glaucoma. This can be achieved by using topical and/or oral medications, laser surgery, conventional surgery, or a combination of these therapies [101]. Current health economics studies on glaucoma treatment mostly focus on direct costs of glaucoma drugs, and therefore provide only one component of real glau- 
coma treatment costs $[100,102,103]$. The main issue that limits this research in the area of glaucoma treatment is absence of a reliable, transparent and validated long-term effectiveness measure [100].

\section{Discussion}

Europe is a continent characterized by high regional variations [2]. The epidemiological rates of visual impairment vary significantly between Western, Central and Eastern Europe and require further review. Moreover, longer life expectancies in developed European countries will increase the prevalence and incidence of age-related eye disorders [32]. Data collection in Europe is currently fragmented due to diverse legal constraints and privacy protection guidelines, which make it difficult to collect patient-related data on a single central server. Furthermore, there is little data exchange among European health care systems, governments and research institutions. Most epidemiological research to date has been performed on the national level; only very few Europewide studies exist.

AMD is the third most frequent cause of blindness globally. It is more frequent in women than in men and tends to increase with age, with a sharper increase in women than men; this can probably be explained by the longer life expectancy of women [13]. The incidence of AMD was also found to increase with age [30]; it was not significantly different between men and women [31]. On average, Western European, such as France [27] and Germany [26], tend to have a higher prevalence of AMD than Eastern European countries, including Russia [29] and Bulgaria [2]. These differences could be explained by the longer life-expectancy of the Western European population in comparison with the population in Eastern Europe [104]. This leads to more individuals in Western Europe surviving until they are diagnosed with AMD in comparison with Eastern Europe. Neovascular AMD was shown to be more prevalent in the UK, although these differences were not statistically significant [28]. It is hard to differentiate these two types at later disease stages. Furthermore, patients with geographic AMD tend to visit an ophthalmologist earlier than those with neovascular AMD [28], which can influence the result of epidemiological data comparison. Cigarette smoking, low dietary intake of vitamin $\mathrm{E}$ and zinc, increased exposure to sunlight and concomitant cardiovascular disease are the main risk factors of AMD [12] that must be tackled during intervention and prevention programmes. Fur-

Epidemiology of Eye Diseases Leading to Blindness ther studies must be done to clarify the source of differences in AMD prevalence between Western and Eastern Europe. All epidemiological studies on the prevalence and incidence of AMD used the same International Classification and Grading System for AMD and ARMD [105]; despite this fact, some of these studies used slightly different age group definitions, which complicated the comparison of age-specific prevalence and incidence between studies. Some studies differentiated AMD by disease stage (early/late) and type (geographic/neovascular), whereas others only defined AMD type.

The natural progression of AMD to geographic atrophy takes an average of 6.6 years (range 4-11) [64]. However, early screening and identification of individuals with a higher risk of AMD together with nutritional and new preventive strategies can slow down this progression. There is an ongoing debate on off-label use of bevacizumab for treatment of wet AMD. As discussed in a Novartis-sponsored literature review on this topic, the issue of off-label bevacitzumab use still remains controversial due to the absence of high-quality and robust RCT data for the comparative efficacy and long-term safety of this treatment approach in comparison with established ones, such as ranibizumab treatment [73].

According to the literature reviewed in this study, diabetic retinopathy affects 3 [32] to 4.1\% [33] of Europeans. Recent epidemiological studies have shown that France [46] and Germany [39] show the highest prevalence of diabetic retinopathy in Europe. Its incidence was quite similar among European countries, being highest in the UK and closely followed by Switzerland, Poland and Germany [34]. This trend can be explained by the higher prevalence of lifestyle risk factors such as systemic hypertension, hyperglycaemia, hypercholesterolaemia, cigarette smoking, and diabetic nephropathy in older Europeans [76]. The incidence of diabetic retinopathy was shown to be higher among men than among women in the 60- to 74-year age range [31]. Furthermore, non-proliferative diabetic retinopathy was the most frequent type in most European countries [42]. Studies on the epidemiology of diabetic retinopathy used different sources for diagnostic standards, e.g. Early Treatment Diabetic Retinopathy Study criteria [106] or the diabetic retinopathy classification described by Fukuda [107]. Nevertheless, the diagnostic criteria appeared to be quite similar, enabling the comparison of results. Several studies graded diabetic retinopathy using stages (minimal, mild and moderate).

Diabetic retinopathy is difficult to identify in early screening when treatment can be most effective. Symp- 
Table 6. Prevalence of high intraocular pressure (IOP) and ocular hypertension (OHT) in Europe

\begin{tabular}{|c|c|c|c|c|c|c|c|c|c|c|c|}
\hline Disease & $\begin{array}{l}\text { Study } \\
\text { location }\end{array}$ & $\begin{array}{l}\text { Study } \\
\text { design }\end{array}$ & $\begin{array}{l}\text { Sample } \\
\text { size }\end{array}$ & Year & Age & Sex & $\begin{array}{l}\text { Prevalence } \\
\%\end{array}$ & $\begin{array}{l}\text { Inci- } \\
\text { dence }\end{array}$ & Grading methods & Methods of diagnosis & $\begin{array}{l}\text { Ref. } \\
\text { No. }\end{array}$ \\
\hline $\begin{array}{l}\text { High } \\
\text { IOP }\end{array}$ & Italy & $\begin{array}{l}\text { population-based } \\
\text { prevalence survey }\end{array}$ & 1,034 & 1997 & $\geq 40$ & both & $\begin{array}{l}6 \\
(4.71-7.61)\end{array}$ & & $\begin{array}{l}\text { glaucomatous VF defects } \\
\text { (sensitivity decrease } \geq 6 \mathrm{db} \text { in } \\
\text { at least } 1 \text { location of the central } \\
10^{\circ}, 2 \text { locations for the central } \\
20^{\circ} \text { or } 3 \text { locations of the central } \\
30^{\circ}, \text { IOP }>20 \mathrm{~mm} \mathrm{Hg}, \mathrm{CDR} \\
>0.5 \text {, difference in CDR }>0.2\end{array}$ & $\begin{array}{l}\text { standardized initial } \\
\text { examination }+ \text { definite } \\
\text { examination with VF } \\
\text { testing }\end{array}$ & 51 \\
\hline \multirow[t]{3}{*}{ OHT } & $\begin{array}{l}\text { Segovia, } \\
\text { Spain }\end{array}$ & $\begin{array}{l}\text { cross-sectional } \\
\text { population-based } \\
\text { study }\end{array}$ & 596 & 2004 & $>60$ & $\begin{array}{l}\text { both } \\
\text { men } \\
\text { women }\end{array}$ & $\begin{array}{l}1.7 \\
1.80 \\
1.60\end{array}$ & $\begin{array}{l}0.9 \\
0.9 \\
0.9\end{array}$ & $\begin{array}{l}\text { diagnostic criteria were } \\
\text { specific to this study OHT IOP } \\
>21 \mathrm{~mm} \mathrm{Hg} \text {, no changes in } \\
\text { optic disc or VF }\end{array}$ & ОРНТН & 48 \\
\hline & France & $\begin{array}{l}\text { cross-sectional } \\
\text { study }\end{array}$ & 3,896 & 2003 & $>18$ & both & 29.50 & & $\begin{array}{l}\text { Terminology and Guidelines } \\
\text { for Glaucoma (ed. 3) }\end{array}$ & $\begin{array}{l}\text { ophthalmological } \\
\text { reports }\end{array}$ & $\begin{array}{l}49 \\
50\end{array}$ \\
\hline & Austria & $\begin{array}{l}\text { long-term } \\
\text { follow-up study }\end{array}$ & 4,864 & 2006 & $\begin{array}{l}\text { adults, no } \\
\text { children }\end{array}$ & both & $\begin{array}{l}2.2 \\
(1.7-2.7)\end{array}$ & & $\begin{array}{l}\text { Terminology and Guidelines } \\
\text { for Glaucoma (ed. 3) }\end{array}$ & OPHTH & 52 \\
\hline
\end{tabular}

VF = Visual field; OPHTH $=$ ophthalmological examination

toms appear only at the stage of proliferative retinopathy or macular oedema. Patients diagnosed with proliferative retinopathy have a very poor prognosis with respect to visual function. However, early screening and prevention programmes have been shown to be cost-effective, and laser coagulation, performed early enough, can stabilize the progression of the disease and prevent blindness.

Glaucoma is one of the leading causes of blindness both in Europe and worldwide [84]. The prevalence of glaucoma ranged widely across Europe; it was highest in Germany [26] and the European North of Russia [29] and lowest in France [50] and the UK [85]. This could be due to the higher frequency of risk factors such as high intraocular pressure, age, various forms of vascular pathology (diabetes, systemic hypotension/hypertension, vasospastic syndrome), myopia, cigarette smoking and alcohol consumption in the former countries [108]. Spanish data showed that open-angle glaucoma is more prevalent in men than in women, but increases in frequency in both sexes over time [48]. The incidence of glaucoma was higher in Germany [87] than in the European North of Russia [56]. Sex-specific glaucoma incidence was also higher in men than in women [31]. A population projection study indicated that open-angle glaucoma will be the most frequent type in 2010 and 2020, and recent studies also show that this type accounts for $80 \%$ of all glaucoma cases [88]. Epidemiologic studies on glaucoma often lacked generally approved diagnostic criteria and used different diag- nostic tests that made it difficult to compare available data.

Early diagnosis of glaucoma is difficult because the disease is asymptomatic in its early stages, when treatment is most beneficial, and it can progress unnoticed. High intraocular pressure is a condition which, if not identified in its early stages, will lead to glaucoma. The overall estimate of the prevalence of ocular hypertension in a Spanish cross-sectional study was 1.7\% (CI 99\%: 1.61.8). Prevalence rates of ocular hypertension did not significantly differ between men (1.8\%) and women (1.6\%) [48]. The prevalence estimate was highest in the age range $40-49(2.6 \%)$, lowest in the age range 50-59 (0.9\%), and homogeneous among those over 60 (1.6-1.7\%) [48]. Overall, the prevalence of ocular hypertension was higher in Austria than in Spain. Cross-sectional studies from France $[49,50]$ used different diagnostic and research approaches and were not comparable with other studies. Despite the importance of data on such high-risk conditions as high intraocular pressure and ocular hypertension, our literature search found only 5 epidemiological studies on the subject. This indicates the importance of much more extensive research to better estimate the prevalence and incidence of these diseases in Europe. The prevalence of high intraocular pressure and ocular hypertension in Europe is shown in table 6. Studies indicate that knowledge about glaucoma was low in the general population of many countries. Glaucoma leads to high societal costs, which are strongly correlated with disease 
severity. Because glaucoma normally does not have warning symptoms, every person older than 50 years of age should be tested for high intraocular pressure.

Previous literature reviews related to the epidemiology of major eye diseases have focused mostly on the incidence of blindness and its causes [109] or on a specific disease within a specific country or geographic region, e.g. AMD [12-14], diabetic retinopathy [15-17], glaucoma $[19,36]$, or cataract [110]. One of the most comprehensive and recent literature reviews was conducted in 2002 within the WHO Programme for the Prevention of Blindness and Deafness and contained data on the prevalence of blindness and low vision in WHO regions as well as on the percentage of total blindness by cause [109]. Nevertheless, data on the prevalence and incidence of major eye diseases were not presented. Furthermore, data on Europe were significantly lacking in comparison with other WHO regions, and a comparison of different countries was not included. The study included results from $25 \mathrm{Eu}-$ ropean population-based studies published between 1982 and 2000. Kocur and Resnikoff [2] reviewed 5 European studies on major eye diseases published from 1970 to 1998. While they summarized the impact of these diseases on visual impairment within each country, they failed to compare epidemiological data among the studies.

The present study compared data from (to the best of the authors' knowledge) all recent European studies concerning the incidence and prevalence of AMD, diabetic retinopathy and glaucoma over a period of 18 years from 1990 to 2008. An overview and comparison of overall and specific prevalence and incidence estimates of major eye diseases in Europe are presented, and the natural progression, the economic impact, and methods of treatment discussed.

The literature search included all papers relevant to the epidemiology of major eye diseases leading to blindness in Europe without restriction to any specific ethnicity. The available publications did not adequately report on the epidemiology of these diseases for non-Caucasian populations. Therefore, the scope of the paper was limited in order to perform a comprehensive analysis of available studies on individuals of Caucasian origin, which represent the majority of the European population. The issue of ethnic differences is quite complicated and, unfortunately, rarely described in the literature. While we were not able to include summary information here, we welcome future research on the topic.

Some caution is advisable when comparing different epidemiological studies, especially from different Euro- pean countries since such studies often use different diagnostic criteria, possibly with different age group definitions and diagnostic methods. This is particularly true of a review of the literature on glaucoma epidemiology since there are no well-established, commonly accepted criteria in Europe for its diagnosis. We attempted to minimize this limitation by using very specific and strict inclusion criteria. The studies reported in this paper used similar diagnostic procedures and approaches. Where differences remained, we have clarified this to ensure the reliability of conclusions derived from this systematic literature review.

Overall, the present study showed that, despite the large number of epidemiological studies of major eye diseases performed worldwide, accurate data are still largely lacking for Europe. This study highlighted the importance of undertaking multicentre, population-based studies of major eye diseases leading to blindness in Europe. Generally approved diagnostic criteria and gold standard screening diagnostic procedures are required to make results of such studies comparable.

The results of the present systematic literature metaanalysis will help policy makers, researchers, patient organizations and pharmaceutical companies to better understand the epidemiology of major eye diseases in $\mathrm{Eu}-$ rope. It is the authors' hope that these results will also lead to the establishment of a common set of preventive measures based on solid epidemiological data and will make it possible to monitor the effects of such prevention and intervention.

\section{Acknowledgments}

We would like to thank Pamela C. Sieving, MA, MS, AHIP for her generous help with the literature search, Dr. Matthew B. Blaschko, for English language assistance, Dr. med. Werner Inhoffen and PD Dr. med. Focke Ziemssen, for providing help in finding important literature on current controversies in the treatment of AMD. European maps in the text are based on templates from the University of Alabama Maps Project [111].

This work was supported by a stipend from the Tistou and Charlotte Kerstan Foundation Vision 2000, EU grant EVIGENORET LSHG-CT-2005-512036. The funding sources for this study had no influence on the study design, the manner in which data were collected, analysed, and interpreted, the writing of the report, or the decision to submit the paper for publication.

\section{Disclosure Statement}

No conflicts of interest exist on the part of any of the authors. 


\section{References}

1 West S, Sommer A: Prevention of blindness and priorities for the future. Bull World Health Organ 2001;79:244-248.

2 Kocur I, Resnikoff S: Visual impairment and blindness in Europe and their prevention. $\mathrm{Br}$ J Ophthalmol 2002;86:716-722.

3 Coleman HR, Chan CC, Ferris FL 3rd, Chew EY: Age-related macular degeneration. Lancet 2008;372:1835-1845.

4 Klein R, Klein BE, Cruickshanks KJ: The prevalence of age-related maculopathy by geographic region and ethnicity. Prog Retin Eye Res 1999;18:371-389.

5 Klein R, Klein BE, Linton KL: Prevalence of age-related maculopathy. The beaver dam eye study. Ophthalmology 1992;99:933-943.

6 Varma R, Fraser-Bell S, Tan S, Klein R, Azen SP: Prevalence of age-related macular degeneration in Latinos: The Los Angeles Latino Eye Study. Ophthalmology 2004;111:12881297.

7 Varma R, Torres M: Prevalence of lens opacities in Latinos: The Los Angeles Latino Eye Study. Ophthalmology 2004;111:1449-1456.

8 Varma R, Torres M, Pena F, Klein R, Azen SP: Prevalence of diabetic retinopathy in adult Latinos: The Los Angeles Latino Eye Study. Ophthalmology 2004;111:1298-1306.

9 Varma R, Ying-Lai M, Francis BA, Nguyen BB, Deneen J, Wilson MR, Azen SP: Prevalence of open-angle glaucoma and ocular hypertension in Latinos: The Los Angeles Latino Eye Study. Ophthalmology 2004;111: 1439-1448.

10 Friedman DS, Jampel HD, Munoz B, West SK: The prevalence of open-angle glaucoma among Blacks and Whites 73 years and older: The Salisbury Eye Evaluation Glaucoma Study. Arch Ophthalmol 2006;124:16251630.

11 Munoz B, West SK, Rubin GS, Schein OD, Quigley HA, Bressler SB, Bandeen-Roche K: Causes of blindness and visual impairment in a population of older Americans: The Salisbury Eye Evaluation Study. Arch Ophthalmol 2000;118:819-825.

12 Smith W, Assink J, Klein R, Mitchell P, Klaver CC, Klein BE, Hofman A, Jensen S, Wang JJ, de Jong PT: Risk factors for age-related macular degeneration: pooled findings from three continents. Ophthalmology 2001; 108:697-704

13 Augood CA, Vingerling JR, de Jong PT, Chakravarthy U, Seland J, Soubrane G, Tomazzoli L, Topouzis F, Bentham G, Rahu M, Vioque J, Young IS, Fletcher AE: Prevalence of age-related maculopathy in older Europeans: The European Eye Study (Eureye). Arch Ophthalmol 2006;124:529535.
14 Astachov US, Lisochkin AB, Shadriev FE: Age-related macular degeneration; in Moshetova LK, Nesterov AP, Ugorov EA (eds): Clinical Ophthalmology Guidelines (in Russian). Moscow, GEOTAR-Media, 2008, pp 164-189.

15 Lee ET, Lu M, Bennett PH, Keen H: Vascular disease in younger-onset diabetes: comparison of European, Asian And American Indian cohorts of the WHO Multinational Study of Vascular Disease In Diabetes. Diabetologia 2001;44(suppl 2):S78-S81.

16 Miki E, Lu M, Lee ET, Keen H, Bennett PH, Russell D: The incidence of visual impairment and its determinants in the WHO Multinational Study of Vascular Disease in Diabetes. Diabetologia 2001;44(suppl 2):S31S36.

17 Horle S, Gruner F, Kroll P: Epidemiology of diabetes-induced blindness - a review (in German). Klin Monbl Augenheilkd 2002; 219:777-784.

18 Topouzis F, Wilson MR, Harris A, Anastasopoulos E, Yu F, Mavroudis L, Pappas T, Koskosas A, Coleman AL: Prevalence of openangle glaucoma in Greece: The Thessalonik Eye Study. Am J Ophthalmol 2007;144:511519.

19 Tuck MW, Crick RP: The age distribution of primary open angle glaucoma. Ophthalmic Epidemiol 1998;5:173-183.

20 Taylor HR: Epidemiology of age-related cataract. Eye (Lond) 1999;13:445-448.

21 Navarro Esteban JJ, Gutierrez Leiva JA, Valero Caracena N, Buendia Bermejo J, Calle Puron ME, Martinez Vizcaino VJ: Prevalence and risk factors of lens opacities in the elderly in Cuenca, Spain. Eur J Ophthalmol 2007; 17:29-37.

22 van Leeuwen R, Klaver CC, Vingerling JR, Hofman A, de Jong PT: The risk and natural course of age-related maculopathy: Followup at $6^{1} / 2$ years in the Rotterdam study. Arch Ophthalmol 2003;121:519-526.

23 Muchamedova AS, Aznabaev RA, Bikbov MM: Ethiopathogenesis of age-related macular degeneration (in Russian). Vestn Oftalmol 2007;123:43-45.

24 Vorobieva MV, Polunin GS, Eliseeva EG: Recent aspects of pathogenesis of age-related macular dystrophy (in Russian). Vestn Oftalmol 2006;122:50-52.

25 Despriet DD, Klaver CC, Witteman JC, Bergen AA, Kardys I, de Maat MP, Boekhoorn SS, Vingerling JR, Hofman A, Oostra BA, Uitterlinden AG, Stijnen T, van Duijn CM, de Jong PT: Complement factor H polymorphism, complement activators, and risk of age-related macular degeneration. JAMA 2006;296:301-309.

26 Gruener F: Prävalenz, Inzidenz und Ursache von Blindheit und wesentlicher Sehbehinderung in Hessen, Marburg; Diss, Marburg, 2001
27 Cohen D, Sartral M, Nounou P, Hamar M, Drouard ME, El Alamy A, Bendeddouche K: Evaluation of moderate and severe visual impairments in patients attending an ophthalmology clinic. A prospective study of 1,172 patients (in French). J Fr Ophtalmol 2000;23: 437-443.

28 Owen CG, Fletcher AE, Donoghue M, Rudnicka AR: How big is the burden of visual loss caused by age related macular degeneration in the United Kingdom? Br J Ophthalmol 2003;87:312-317.

29 Bannikova RV, Sannikov AL, Konovalov AV: Characteristics of ophthalmic pathology under the conditions of the European North of Russia (in Russian). Probl Sotsialnoi Gig Zdravookhranenniiai Istor Med 2002:3536.

30 Klaver CC, Assink JJ, van Leeuwen R, Wolfs RC, Vingerling JR, Stijnen T, Hofman A, de Jong PT: Incidence and progression rates of age-related maculopathy: the Rotterdam study. Invest Ophthalmol Vis Sci 2001;42: 2237-2241.

31 Krumpaszky HG, Ludtke R, Mickler A, Klauss V, Selbmann HK: Blindness incidence in Germany. A population-based study from Württemberg-Hohenzollern. Ophthalmologica 1999;213:176-182.

32 Resnikoff S, Pascolini D, Etya'ale D, Kocur I, Pararajasegaram R, Pokharel GP, Mariotti SP: Global data on visual impairment in the year 2002. Bull World Health Organ 2004; 82:844-851.

33 Simmons D, Clover G, Hope C: Ethnic differences in diabetic retinopathy. Diabet Med 2007;24:1093-1098.

34 Keen H, Lee ET, Russell D, Miki E, Bennett $\mathrm{PH}, \mathrm{Lu} \mathrm{M}$ : The appearance of retinopathy and progression to proliferative retinopathy: the WHO Multinational Study of Vascular Disease in Diabetes. Diabetologia 2001; 44(suppl 2):S22-S30.

35 Shurshukov YY, Konovalov IM, Savelieva ES, Konovalova AV: Investigation of distribution of eye diseases and supplementary apparatus basing on the monitoring data (in Russian). Zdravoochrananie Rossiiskoi Federatii 2007:53-54.

36 Alabyeva GU, Nesterov AP: Glaucoma; in Moshetova LK, Nesterov AP, Ugorov EA (eds): Clinical Ophthalmology Guidelines (in Russian). Moscow, GEOTAR-Media, 2008, pp 97-124.

37 Moshetova LK, Nesterov AP, Ugorov EA: Diabetic Retinopathy; in Moshetova LK, Nesterov AP, Ugorov EA (eds): Clinical Ophthalmology Guidelines (in Russian). Moscow, GEOTAR-Media, 2008, pp 139-140. 
38 Fernandez-Vigo J, Sanchez Macho J, Diaz Rey A, Barros J, Tome M, Bueno J: The prevalence of diabetic retinopathy in Northwest Spain. An epidemiological study of diabetic retinopathy in Galicia. I. Acta Ophthalmol (Copenh) 1993;71:22-26.

39 Blum M, Kloos C, Muller N, Mandecka A, Berner R, Bertram B, Muller UA: Prevalence of diabetic retinopathy. Check-up program of a public health insurance company in Germany 2002-2004 (in German). Ophthalmologe 2007;104:499-500, 502-494.

40 Hesse L, Grusser M, Hoffstadt K, Jorgens V, Hartmann P, Kroll P: Population-based study of diabetic retinopathy in Wolfsburg (in German). Ophthalmologe 2001;98:10651068.

41 Giuffre G, Lodato G, Dardanoni G: Prevalence and risk factors of diabetic retinopathy in adult and elderly subjects: The Casteldaccia Eye Study. Graefes Arch Clin Exp Ophthalmol 2004;242:535-540.

42 Sparrow JM, McLeod BK, Smith TD, Birch MK, Rosenthal AR: The prevalence of diabetic retinopathy and maculopathy and their risk factors in the non-insulin-treated diabetic patients of an English town. Eye (Lond) 1993; 7:158-163.

43 Teruel Maicas C, Fernandez-Real JM, Ricart W, Valent Ferrer R, Valles Prats M: Prevalence of diabetic retinopathy in the region of Girona. Study of related factors (in Spanish). Arch Soc Esp Oftalmol 2005;80:85-91.

44 Lopez IM, Diez A, Velilla S, Rueda A, Alvarez A, Pastor CJ: Prevalence of diabetic retinopathy and eye care in a rural area of Spain. Ophthalmic Epidemiol 2002;9:205-214.

45 Skenduli-Bala E, de Voogd S, Wolfs RC, van Leeuwen R, Ikram MK, Jonas JB, Bakker D, Hofman A, de Jong PT: Causes of incident visual field loss in a general elderly population: The Rotterdam study. Arch Ophthalmol 2005; 123:233-238.

46 Waked N, Saad A, Mehanna C, Sleilaty G, Kortbaoui R: Prevalence, causes, and risk factors for blindness and visual impairment among nursing home residents in Lebanon (in French). J Fr Ophtalmol 2007;30:497502 .

47 Santos Bueso E, Fernandez-Vigo J, Fernandez Perez C, Macarro Merino A, Fernandez Perianes J: Prevalence of diabetic retinopathy in the regional community of Extremadura. 1997-2001 (Extremadura Project to Prevent Blindness) (in Spanish). Arch Soc Esp Oftalmol 2005;80:187-194.

48 Anton A, Andrada MT, Mujica V, Calle MA, Portela J, Mayo A: Prevalence of primary open-angle glaucoma in a spanish population: The Segovia study. J Glaucoma 2004;13: 371-376.

49 Villain M, Nordmann JP, Renard JP, Bron A, Delcourt C, Pinchinat S, Solesse de Gendre A, Pelen F: The French glaucoma and ocular hypertension 1-day study (in French). J Fr Ophtalmol 2006;29:520-525.
50 Weinreb RN, Khaw PT: Primary open-angle glaucoma. Lancet 2004;363:1711-1720.

51 Cedrone C, Culasso F, Cesareo M, Zapelloni A, Cedrone P, Cerulli L: Prevalence of glaucoma in Ponza, italy: a comparison with other studies. Ophthalmic Epidemiol 1997;4: $59-72$.

52 Hitzl W, Ortner C, Hornykewycz K, Grabner G, Reitsamer HA: Resource use and costs for a glaucoma screening program in Austria: an 8-year review: a cost-consequence analysis based on the Salzburg-Moorfields Collaborative Glaucoma Study. Eur J Ophthalmol 2006;16:92-99.

53 Tuck MW, Crick RP: The projected increase in glaucoma due to an ageing population. Ophthalmic Physiol Opt 2003;23:175-179.

54 Kroese M, Burton H, Vardy S, Rimmer T, McCarter D: Prevalence of primary open angle glaucoma in general ophthalmic practice in the United Kingdom. Br J Ophthalmol 2002;86:978-980.

55 Nesterov AP: Glaucoma, ocular hypertension; in Kopaeva VG (ed): Eye Diseases (in Russian). Moscow, Medicine, 2002, pp $353-$ 385.

56 Morbidity of the population of Arkhangelsk Oblast in 2006: Statistical Data, Arkhangelsk Oblast Administration, Department of Public Health, Medical Information Center. 2007, pp 19-140.

57 Krumpaszky HG, Klauss V: Epidemiology of blindness and eye disease. Ophthalmologica 1996;210:1-84.

58 Gohdes DM, Balamurugan A, Larsen BA, Maylahn C: Age-related eye diseases: an emerging challenge for public health professionals. Prev Chronic Dis 2005;2:A17.

59 Verma L, Das T, Binder S, Heriot WJ, Kirchhof B, Venkatesh P, Krebs I, Stolba U, Jahn C, Feichtinger H, Kellner L, Krugluger $\mathrm{H}$ Pawelka I, Frohner U, Kruger A, Li W, Tewari HK: New approaches in the management of choroidal neovascular membrane in age-related macular degeneration. Indian J Ophthalmol 2000;48:263-278.

60 Laser photocoagulation for juxtafoveal choroidal neovascularization. Five-year results from randomized clinical trials. Macular photocoagulation study group. Arch Ophthalmol 1994;112:500-509.

61 Rubin GS, Bressler NM: Effects of verteporfin therapy on contrast on sensitivity: results from the treatment of age-related macular degeneration with photodynamic therapy (TAP) investigation - TAP report No 4. Retina 2002;22:536-544.

62 Oliver-Fernandez A, Bakal J, Segal S, Shah GK, Dugar A, Sharma S: Progression of visual loss and time between initial assessment and treatment of wet age-related macular degeneration. Can J Ophthalmol 2005;40:313319.
63 Klein ML, Ferris FL, 3rd, Armstrong J, Hwang TS, Chew EY, Bressler SB, Chandra SR: Retinal precursors and the development of geographic atrophy in age-related macular degeneration. Ophthalmology 2008; 115 : 1026-1031.

64 Cruess AF, Zlateva G, Xu X, Soubrane G, Pauleikhoff D, Lotery A, Mones J, Buggage R, Schaefer C, Knight T, Goss TF: Economic burden of bilateral neovascular age-related macular degeneration: Multi-country observational study. Pharmacoeconomics 2008; 26:57-73.

65 Coleman AL, Yu F: Eye-related medicare costs for patients with age-related macular degeneration from 1995 to 1999. Ophthalmology 2008; $115: 18-25$.

66 Brown MM, Brown GC, Brown HC, Peet J: A value-based medicine analysis of ranibizumab for the treatment of subfoveal neovascular macular degeneration. Ophthalmology 2008;115:1039-1045.

67 A randomized, placebo-controlled, clinical trial of high-dose supplementation with vitamins $C$ and $E, \beta$-carotene, and zinc for agerelated macular degeneration and vision loss: AREDS report No 8. Arch Ophthalmol 2001;119:1417-1436.

68 Javitt JC, Zlateva GP, Earnshaw SR, Pleil AM, Graham CN, Brogan AJ, Shah SN, Adamis AP: Cost-effectiveness model for neovascular age-related macular degeneration: comparing early and late treatment with pegaptanib sodium based on visual acuity. Value Health 2008;11:563-574.

69 Hopley C, Salkeld G, Mitchell P: Cost utility of photodynamic therapy for predominantly classic neovascular age related macular degeneration. Br J Ophthalmol 2004;88:982987.

70 Brown GC, Brown MM, Sharma S, Brown H, Tasman W: Incremental cost effectiveness of laser photocoagulation for subfoveal choroidal neovascularization. Ophthalmology 2000;107:1374-1380.

71 Brown GC, Brown MM, Brown HC, Kindermann S, Sharma S: A value-based medicine comparison of interventions for subfoveal neovascular macular degeneration. Ophthalmology 2007;114:1170-1178.

72 Busbee BG, Brown MM, Brown GC, Sharma S: CME review: a cost-utility analysis of laser photocoagulation for extrafoveal choroidal neovascularization. Retina 2003;23:279287; quiz 443-444.

73 Mitchell P, Annemans L, White R, Gallagher M, Thomas S: Cost effectiveness of treatments for wet age-related macular degeneration. Pharmacoeconomics 2011;29:107-131.

74 Harvey PT: Common eye diseases of elderly people: identifying and treating causes of vision loss. Gerontology 2003;49:1-11.

75 Kristinsson JK: Diabetic retinopathy. Screening and prevention of blindness; thesis. Acta Ophthalmol Scand Suppl 1997:1-76.

76 Infeld DA, O'Shea JG: Diabetic retinopathy. Postgrad Med J 1998;74:129-133. 
77 Idil A, Caliskan D, Ocaktan E: The prevalence of blindness and low vision in older onset diabetes mellitus and associated factors: a community-based study. Eur J Ophthalmol 2004; $14: 298-305$

78 Davies R, Sullivan P, Canning C: Simulation of diabetic eye disease to compare screening policies. Br J Ophthalmol 1996;80:945-950.

79 Hirskyj P: QALY: an ethical issue that dare not speak its name. Nurs Ethics 2007;14:7282.

80 Javitt JC, Aiello LP: Cost-effectiveness of detecting and treating diabetic retinopathy. Ann Intern Med 1996;124:164-169.

81 Hamilton AMP, Ulbig MW, Polkinghorne P: Managment of diabetic retinopathy. London, BMJ Publishing Group, 1996

82 Michelson G, Groh MJ: Screening models for glaucoma. Curr Opin Ophthalmol 2001;12: 105-111.

83 Bourne RR: Worldwide glaucoma through the looking glass. Br J Ophthalmol 2006;90: 253-254.

84 Thylefors B, Negrel AD: The global impact of glaucoma. Bull World Health Organ 1994; 72:323-326.

85 Gray SF, Spry PG, Brookes ST, Peters TJ, Spencer IC, Baker IA, Sparrow JM, Easty DL: The Bristol Shared Care Glaucoma Study: outcome at follow-up at 2 years. Br J Ophthalmol 2000;84:456-463.

86 Owen CG, Carey IM, De Wilde S, Whincup PH, Wormald R, Cook DG: The epidemiology of medical treatment for glaucoma and ocular hypertension in the United Kingdom: 1994 to 2003. Br J Ophthalmol 2006;90:861868 .

87 Trautner C, Haastert B, Richter B, Berger M, Giani G: Incidence of blindness in Southern Germany due to glaucoma and degenerative conditions. Invest Ophthalmol Vis Sci 2003; 44:1031-1034.

88 Quigley HA, Broman AT: The number of people with glaucoma worldwide in 2010 and 2020. Br J Ophthalmol 2006;90:262-267.

89 Gupta N, Weinreb RN: New definitions of glaucoma. Curr Opin Ophthalmol 1997;8: 38-41.
90 Hitzl W, Hornykewycz K, Grabner G, Reitsamer HA: On the relationship between age and prevalence and/or incidence of primary open-angle glaucoma in the 'SalzburgMoorfields collaborative glaucoma study' (in German). Klin Monbl Augenheilkd 2007;224:115-119.

91 Tuulonen A, Airaksinen PJ, Erola E, Forsman E, Friberg K, Kaila M, Klemetti A, Makela M, Oskala P, Puska P, Suoranta L, Teir H, Uusitalo H, Vainio-Jylha E, Vuor ML: The Finnish evidence-based guideline for open-angle glaucoma. Acta Ophthalmol Scand 2003;81:3-18.

92 Krieglstein GK: Blindness caused by glaucoma (in German). Ophthalmologe 1993; 90:554-556.

93 Saw SM, Gazzard G, Friedman D, Foster PJ, Devereux JG, Wong ML, Seah S: Awareness of glaucoma, and health beliefs of patients suffering primary acute angle closure. $\mathrm{Br}$ Ophthalmol 2003;87:446-449.

94 Lee BL, Wilson MR: Ocular Hypertension Treatment Study (OHTS) commentary. Curr Opin Ophthalmol 2003;14:74-77.

95 Koleva D, Motterlini N, Schiavone M, Garattini L: Medical costs of glaucoma and ocular hypertension in Italian referral centres: a prospective study. Ophthalmologica 2007;221:340-347.

96 Traverso CE, Walt JG, Kelly SP, Hommer AH, Bron AM, Denis P, Nordmann JP, Renard JP, Bayer A, Grehn F, Pfeiffer N, Cedrone C, Gandolfi S, Orzalesi N, Nucci C, Rossetti L, Azuara-Blanco A, Bagnis A, Hitchings R, Salmon JF, Bricola G, Buchholz PM, Kotak SV, Katz LM, Siegartel LR, Doyle JJ: Direct costs of glaucoma and severity of the disease: a multinational longterm study of resource utilisation in $\mathrm{Eu}$ rope. Br J Ophthalmol 2005;89:1245-1249.

97 Huang TC, Lee DA: Punctal occlusion and topical medications for glaucoma. Am J Ophthalmol 1989;107:151-155.

98 Ariturk N, Oge I, Erkan D, Sullu Y, Sahin $\mathrm{M}$ : The effects of nasolacrimal canal blockage on topical medications for glaucoma Acta Ophthalmol Scand 1996;74:411-413.

99 Drance SM, Nash PA: The dose response of human intraocular pressure to pilocarpine. Can J Ophthalmol 1971;6:9-13.
100 European Glaucoma Society. Terminology and Guidelines for Glaucoma, ed 3. Savana, Dagma, 2008.

101 Johnson LN: Glaucoma: our role in reducing the burden of blindness. J Natl Med Assoc 2002;94:908-911.

102 Schmier JK, Halpern MT, Jones ML: The economic implications of glaucoma: a literature review. Pharmacoeconomics 2007; 25:287-308.

103 Orme M, Boler A: Prostaglandin analogues for the treatment of glaucoma and ocular hypertension: a systematic review of economic evidence. Pharmacoeconomics 2006;24:743-750.

104 Brainerd EL: Life expectancy in Eastern Europe. Science 2000;290:52-53.

105 Bird AC, Bressler NM, Bressler SB, Chisholm IH, Coscas G, Davis MD, de Jong PT, Klaver CC, Klein BE, Klein R, et al: An international classification and grading system for age-related maculopathy and agerelated macular degeneration. The International Arm Epidemiological Study Group. Surv Ophthalmol 1995;39:367-374.

106 Early treatment diabetic retinopathy study design and baseline patient characteristics. ETDRS report No 7. Ophthalmology 1991; 98:741-756

107 Fukuda M: Classification and treatment of diabetic retinopathy. Diabetes Res Clin Pract 1994;24(suppl):S171-S176.

108 Weih LM, Nanjan M, McCarty CA, Taylor HR: Prevalence and predictors of open-angle glaucoma: results from the visual impairment project. Ophthalmology 2001; 108:1966-1972.

109 Pascolini D, Mariotti SP, Pokharel GP, Pararajasegaram R, Etya'ale D, Negrel AD, Resnikoff S: 2002 global update of available data on visual impairment: a compilation of population-based prevalence studies. Ophthalmic Epidemiol 2004;11:67-115.

110 Acosta R, Hoffmeister L, Roman R, Comas M, Castilla M, Castells X: Systematic review of population-based studies of the prevalence of cataracts (in Spanish). Arch Soc Esp Oftalmol 2006;81:509-516.

111 Alabama, Cartographic Research Laboratory, University of Alabama: Alabama maps project, 2009. 